\title{
Application of experimental design methodology to optimize antibiotics removal by walnut shell based activated
}

\section{carbon}

\author{
S.Teixeira \\ C.Delerue-Matos \\ L.Santos
}

\section{Highlights}

-Walnut shell based activated carbon was tested for adsorption of two antibiotics.

-The role of $\mathrm{pH}$ and temperature, on the removal, was studied by a Box-Behnken design.

-The $\mathrm{pH}$ had the highest effect on Metronidazole (MNZ) removal.

-The temperature had the greatest influence on Sulfamethoxazole (SMX) removal.

-Langmuir maximum sorption capacities of $107.4 \mathrm{mg} / \mathrm{g}$ for MNZ and $93.5 \mathrm{mg} / \mathrm{g}$ for SMX

\section{Abstract}

Three-level Box-Behnken experimental design with three factors $(\mathrm{pH}$, temperature and antibiotic initial concentration) combined with response surface methodology (RSM) was applied to study the removal of Metronidazole and Sulfamethoxazole by walnut shell based activated carbon. This methodology enabled to identify the effects of the different factors studied and their interactions in the response of each antibiotic. The relationship between the independent variable (sorption capacity) and the dependent variables $(\mathrm{pH}$, temperature and antibiotic concentration) was adequately modelled by second-order polynomial equation. The $\mathrm{pH}$ factor exerted a significant but distinct influence on the removal efficiency of both antibiotics. The removal of Metronidazole is favoured by 
increasing $\mathrm{pH}$ values, with the maximum value obtained for $\mathrm{pH} 8$ - upper limit of the study domain; while Sulfamethoxazole displays a maximum value around 5.5, with a decrease in the extent of adsorption as the $\mathrm{pH}$ increases. The best conditions, predicted by the model, for the removal of the antibiotic Sulfamethoxazole $(106.9 \mathrm{mg} / \mathrm{g})$ are obtained at a temperature of $30^{\circ} \mathrm{C}$, initial concentration of $40 \mathrm{mg} / \mathrm{L}$ and a $\mathrm{pH}$ value of 5.5. For the antibiotic Metronidazole, the highest removal value $(127 \mathrm{mg} / \mathrm{g})$ is expected to occur at the maximum levels attributed to each of the factors $\left(\mathrm{pH}=8, \mathrm{C}_{\mathrm{in}}=40 \mathrm{mg} / \mathrm{L}\right.$, $T=30^{\circ} \mathrm{C}$ ). The results of isotherm experiments (at $20^{\circ} \mathrm{C}$ and $\mathrm{pH}$ ) displayed a good agreement with the models predictions. The maximum sorption capacity, estimated by the Langmuir model, was $107.4 \mathrm{mg} / \mathrm{g}$ for Metronidazole and $93.5 \mathrm{mg} / \mathrm{g}$ for Sulfamethoxazole.

\section{Graphical abstract}

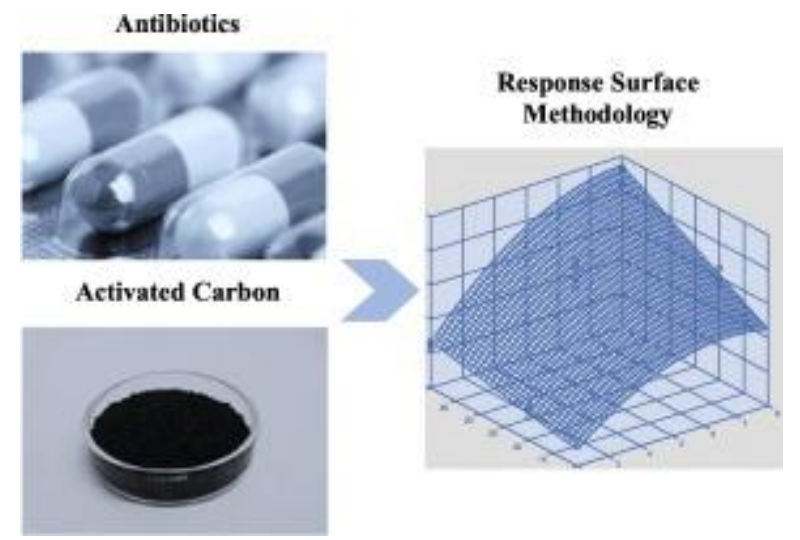

\section{Keywords}

Antibiotics

Walnut Shell

Activated carbon

Removal

Box-Behnken

Response surface methodology 


\section{Introduction}

Recently, a significant number of studies regarding the environmental occurrence and fate of pharmaceuticals and personal care products (PPCPs) have been published. These substances are released to environmental waters both directly and indirectly through a range of diffuse and point source pathways (H. Jones et al., 2005; Khetan and Collins, 2007; Papageorgiou et al., 2016).

Antibiotics are among the most commonly reported PPCPs compounds currently reported to occur in the water cycle (surface water, groundwater, drinking water and wastewaters) as well as in the soil, sewage sludge and sediments (Arpin-Pont et al., 2016; $\underline{\text { Carvalho and }}$ Santos, 2016; Gros et al., 2012; Kümmerer, 2009a; Loos et al., 2009, Loos et al., 2010; Teijon et al., 2010; Thiele-Bruhn, 2003). The widespread use of antibiotics has led to a growing concern in the occurrence and fate of their residues in the environment. The emergence and spread of antimicrobial resistance has become a major public health problem world-wide. The inappropriate use of therapeutic antimicrobials in human and veterinary medicine, the use of antimicrobials for non-therapeutic purposes contributed to the emergence and spread of resistant microorganisms (Kümmerer, 2009b; SandeBruinsma et al., 2008; Tello et al., 2012). The potential of antibiotics to induce the development of resistant strains of bacteria and to maintain populations of resistant strains is one of main issues that their occurrence in the environment raise (Huerta et al., 2013; Tello et al., 2012). Metronidazole and Sulfamethoxazole are two antibiotics widely used in human and veterinary medicine. These compounds have been entering the environment for decades. Water and soil have been shown to contain measurable amounts of both antibiotics (Arpin-Pont et al., 2016; Lindberg et al., 2004; Loos et al., 2009, Loos et al., 2010; Paíga et al., 2016; Tolls, 2001).The main route of Metronidazole and Sulfamethoxazole antibiotics into the environment is via sewage treatment plants. Both antibiotics are ineffectively removed by conventional treatment systems and their occurrence has been well documented, especially Sulfamethoxazole, which is one of the most detected pharmaceutical compounds (Coutu et al., 2013; Kasprzyk-Hordern et al., 2009; Kovalova et al., 2012; Loos et al., 2012; López-Serna et al., 2013).

Advanced treatment of municipal wastewater, for example, has been shown to significantly reduce the presence of several PPCPs substances, as well as antibiotics, in 
treated effluent discharged to receiving waters. Recent research indicates that treatment processes, such as ozonation, advanced oxidation, membrane separation (e.g. nanofiltration, reverse osmosis) and adsorption on activated carbon, or combined treatment processes should be taken into consideration to ensure successful treatment of the variety of micropollutants (Joss et al., 2008; Kovalova et al., 2013; Reungoat et al., 2012; Snyder et al., 2007; Vieno et al., 2007).

Activated carbon is a common process applied to remove a broad spectrum of dissolved organic and inorganic species from both gas phase and liquid phase. This great flexibility in the applications of activated carbons arises from the wide range of not only physical surface properties but also chemical properties of commercially available and/or specifically treated carbon materials (Moreno-Castilla, 2004).

Several agricultural and wood by-products have been study as an inexpensive and renewable additional source for activated carbon production (Gupta et al., 2009). These are normally waste materials with little or no economic value and often present a disposal problem. In addition, the demand for activated carbon has been increasing worldwide, and it is expected to continue raising in the near future (Roskill, 2016). Walnut shells are among the wide range of lignocellulosic waste materials that have been suggested as efficient sorbent alternatives (Gupta et al., 2009). Due to the low ash content, bulk density and mechanical properties it has been used as low-cost sorbent for metal and oil removal but also as precursor material for activated carbon production ( $\underline{\mathrm{Hu} \text { and Vansant, 1995; }}$

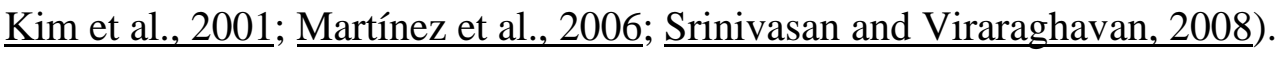

Granular activated carbon (GAC) and powdered activated carbon (PAC) are increasingly adopted in water treatment to remove pesticides and improve taste and odour, and these processes have been shown to be able to remove several pharmaceuticals, including antibiotics, by adsorption (often followed by biodegradation on the GAC surface biofilm) (Carvalho and Santos, 2016; Flores-Cano et al., 2016; Homem and Santos, 2011; RiveraUtrilla et al., 2013).

Activated carbon capacity is strongly dependent on the pore structure (pore shape/size and volume) and surface chemistry properties (e.g. functional groups and point of zero charge). Although the activated carbon surface is predominantly hydrophobic it might also contain several polar functional groups. These groups contain some heteroatoms, 
mainly oxygen, but may also contain nitrogen and sulfur. The nature of these functional groups depends on activation conditions and contributes to the acid/base character of the surface and to specific interactions with adsorbed compounds (Moreno-Castilla, 2004;

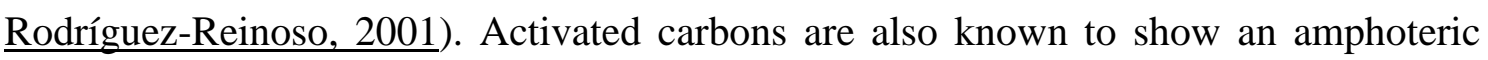
character in aqueous solutions; their surface charge density depends on the solution $\mathrm{pH}$. Besides activated carbon properties, the ability to remove organic micro-pollutants depends on the solution chemistry (e.g. $\mathrm{pH}$, ion strength and temperature), as well as the contaminant properties (e.g. water solubility, hydrophobicity, charge, polarizability, size, aromaticity and the presence of specific functional groups) (Moreno-Castilla, 2004; Rodríguez-Reinoso, 2001). The solution $\mathrm{pH}$ is one of the most important parameters since it simultaneously affects the surface charge of the activated carbon and the ionization/speciation of the solutes, with effects on its solubility and hydrophobicity (Gao and Pedersen, 2005; Haghseresht et al., 2001; Ji et al., 2009; Yang et al., 2011; Zhang et al., 2010; Teixeira et al., 2012).

The availability of adsorption data for PPCPs is still limited. Most of the studies on the removal of $\mathrm{PPCP}_{\mathrm{S}}$, including antibiotics, have been carried out by testing a broad range of compounds in bench scale experiments, pilot-scale or by directly evaluating removals through full-scale facilities. In these studies, the removal efficiencies of the antibiotics Metronidazole and Sulfamethoxazole ranged from less than 2\% up to $98 \%$ (Kovalova et

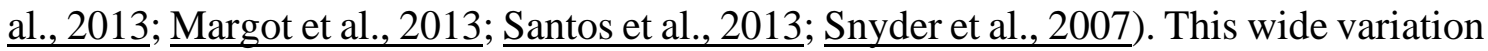
among studies is due to several factors such as the frequency of activated carbon regeneration/replacement, the presence of natural organic matter, activated carbon type (e.g. porosity, surface chemistry), compounds proprieties and solution chemistry.

There is, therefore, a need to study and optimize the removal conditions for a better understanding of the removal mechanism(s) and higher GAC performance. In this paper, a three-level Box-Behnken design was employed with response surface methodology (RSM) to maximize the removal of the two target antibiotics. Discussion highlights the influence of $\mathrm{pH}$, temperature solution and antibiotic characteristics on the sorption process.

\section{Materials and methods}




\subsection{Reagents and materials}

Metronidazole and Sulfamethoxazole were purchased from Sigma-Aldrich (Sintra, Portugal). The physicochemical properties and the chemical structures of both compounds are listed in Table 1. Individual stock standard solutions at a concentration of $1 \mathrm{~g} / \mathrm{L}$ were prepared in methanol and stored at $-18^{\circ} \mathrm{C}$ in dark glass vials. Working standard solutions were prepared daily by appropriate dilution of the stock solution with water. The water was distilled, deionized, and filtered through $0.45 \mu \mathrm{m}$ nylon membrane filters (Sigma-Aldrich). Methanol and acetonitrile (ACN) were of HPLC grade. These solvents were obtained from VWR (Porto, Portugal). Sodium phosphate monobasic monohydrate (purity $>99.0 \%$ ) and sodium phosphate (purity $>99.0 \%$ ) were purchased from Sigma-Aldrich. Citric acid monohydrate (purity $>99.0 \%$ ), hydrochloric acid, sodium hydroxide and sodium chloride (purity $>99.0 \%$ ), were obtained from VWR. Standard hydrochloric acid $(0.1 \mathrm{M})$ and sodium hydroxide solutions $(0.1 \mathrm{M})$ were purchased from Sigma-Aldrich.

Table 1. Textural properties, $\mathrm{pH}_{\mathrm{pcz}}$ and total acidity and basicity.

$$
S_{\text {Bet }}\left(\mathrm{m}^{2} / \mathrm{g}\right) \mathrm{V}^{\mathrm{a}}\left(\mathrm{cm}^{3} / \mathrm{g}\right) \mathrm{pH}_{\mathrm{pcz}}
$$

\section{Total acidity Total basicity}

(meq/100 g activated carbon)

$$
0.457
$$

$$
6.08 \pm 0.03138 .5 \pm 5.2
$$$$
34.7 \pm 1.8
$$

a

Volume of pores with diameter between 2 and $0.61 \mathrm{~nm}$ (determined by $\mathrm{N}_{2}$; DFT method).

\subsection{Activated carbon}

The starting material (walnut shell; by-product of agricultural production obtained in the northern region of Portugal) was grounded and sieved. The fraction $1000 \mu \mathrm{m}<\mathrm{d}<2000 \mu \mathrm{m}$ was selected and then washed with deionized water, oven-dried for $48 \mathrm{~h}$ at $105^{\circ} \mathrm{C}$, and kept in a controlled humidity atmosphere. These samples were pyrolyzed at $300^{\circ} \mathrm{C}$, for an hour, in nitrogen atmosphere. The walnut char was then impregnated with $\mathrm{K}_{2} \mathrm{CO}_{3}$ solution (activating agent; impregnation ratio of 1:1), at room temperature, and finally heated at $105^{\circ} \mathrm{C}$, for $8 \mathrm{~h}$, with a total preparation time of 
approximately $24 \mathrm{~h}$ (impregnation and drying). The materials were then placed in a vertical furnace for activation. Nitrogen gas was used as a purge gas for $20 \mathrm{~min}$ before heating up. The impregnated char was heated at $10^{\circ} \mathrm{C} / \mathrm{min}$ until the desired temperature $\left(900^{\circ} \mathrm{C}\right)$ was achieved and held for $1 \mathrm{~h}$, in an inert atmosphere $\left(\mathrm{N}_{2}\right.$ at $\left.200 \mathrm{~mL} / \mathrm{min}\right)$. The activated carbon was thoroughly washed, dried at $105^{\circ} \mathrm{C}$, sieved (the fraction $710 \mu \mathrm{m}<\mathrm{d}<1000 \mu \mathrm{m}$ was employed) and finally placed in desiccator before further use.

The basicity and acidity of the carbon material were determined by a procedure reported elsewhere (Pereira et al., 2003). Briefly, $100 \mathrm{mg}$ of activated carbon was added to $25 \mathrm{~mL}$ of $\mathrm{HCl}$ solution $(0.05 \mathrm{M}$; basicity estimation) or $\mathrm{NaOH}$ solution $(0.1 \mathrm{M}$; acidity determination) in a capped Erlenmeyer flask and equilibrated for $48 \mathrm{~h}$, in a thermostatically controlled incubator (Lovibond, Dortmund, Germany) at $20^{\circ} \mathrm{C}$ with magnetic agitation (Multistirrer 15, Velp Scientifica, Milan, Italy). The solutions were filtrated and subsequently back-titrated (aliquots of $10 \mathrm{~mL}$, in duplicate) with $\mathrm{NaOH}$ (0.1 M; basicity estimation) or $\mathrm{HCl}$ solution ( $0.1 \mathrm{M}$; acidity determination). Blank tests were also carried out. The point of zero charge $\left(\mathrm{pH}_{\mathrm{pzc}}\right)$ was determined by the $\mathrm{pH}$ drift method (Ferro-García et al., 1998). A Crison GLP 21 pH-meter (Barcelona, Spain) with a combined glass electrode was used and the solutions were stirred and bubbled with purified nitrogen during the $\mathrm{pH}$ measurements (to avoid $\mathrm{CO}_{2}$ dissolution). The $\mathrm{pH}$ of a $0.01 \mathrm{M} \mathrm{NaCl}$ solution was adjusted to a value between 2 and 10 using diluted solutions of $\mathrm{HCl}$ or $\mathrm{NaOH}$. The activated carbon $(25 \mathrm{mg})$ was added to $50 \mathrm{~mL}$ of the $\mathrm{pH}$ adjusted solution in a capped Erlenmeyer flask and equilibrated for $48 \mathrm{~h}$, in a thermostatically controlled incubator (Lovibond) at $20{ }^{\circ} \mathrm{C}$ with magnetic agitation (Multistirrer 15, Velp Scientifica). The final $\mathrm{pH}$ was measured and plotted against the initial $\mathrm{pH}$. The $\mathrm{pH}$ at which the curve crosses the $\mathrm{pH}_{\text {initial }}=\mathrm{pH}_{\text {final }}$ line was taken as the point of zero charge. $\mathrm{pH}_{\mathrm{pzc}}$ assays were performed in duplicate. The $\mathrm{S}_{\mathrm{BET}}$ and micropore volume were obtained from the $\mathrm{N}_{2}$ isotherms at $-196{ }^{\circ} \mathrm{C}$ (Autosorb ${ }^{\mathrm{TM}}$ - QuantaChrome, Florida, USA). The main textural and chemical characteristics of the activated carbon are summarized in Table 2.

Table 2. Physicochemical properties of the target antibiotics. 


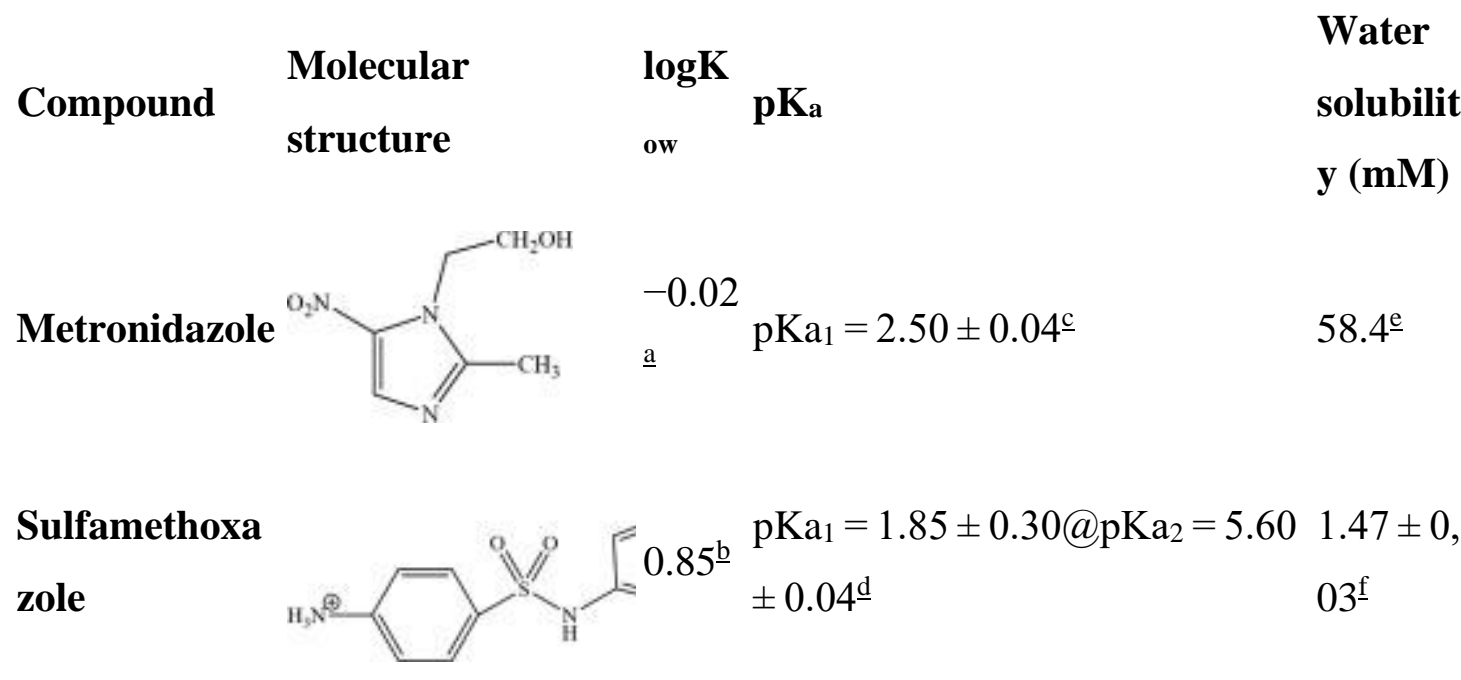

a

Data from: (Davis et al., 2006).

b

Data from: (Carda-Broch and Berthod, 2004).

C

Data from: (Royer et al., 2009).

d

Data from: (Qiang and Adams, 2004).

e

Data from: (Wu and Fassihi, 2005).

f

Data from: (Martínez et al., 2003).

\subsection{Sorption studies}

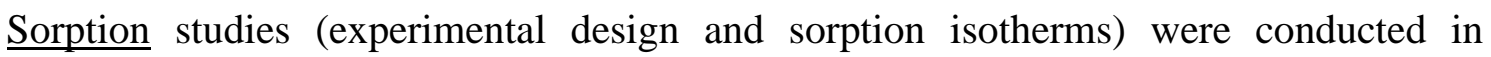
Erlenmeyer closed flasks, equilibrated in a thermostatically controlled incubator 
(Lovibond) with magnetic agitation (Multistirrer 15, Velp Scientifica). Preliminary kinetic tests were carried out in order to determine the equilibrium time. A contact time of $48 \mathrm{~h}$ was enough to allow the equilibrium between the two phases (solid/liquid) for all the experimental conditions considered in this study. Sorption experiments were performed in citrate ( $\mathrm{pH} 2$ and 5) and phosphate (pH 6 and 8) buffers with initial concentration of $20 \mathrm{mM}$ and $\mathrm{pH}$ adjusted with diluted solutions of $\mathrm{HCl}$ or $\mathrm{NaOH}$ to the desired value. In parallel, blank assays were prepared without activated carbon or antibiotic. Triplicate samples were evaluated for each set of conditions and the average values are reported. The solutions were filtered through $0.20 \mu \mathrm{m}$ PTFE syringe filter (VWR) before HPLC analysis. Sorption isotherms experiments were conducted for initial antibiotic concentrations ranging from 0.50 to $40 \mathrm{mg} / \mathrm{L}$ and activated carbon amount of $10 \mathrm{mg}$.

\subsection{Experimental design}

Experimental design and Response Surface Methodology (RSM) are useful statistical techniques that can be used to identify and optimize the relevant factors that influence a specific process (Dean and Voss, 1999). It is an experimental strategy to obtain the optimum conditions for a multivariable system. One of the most common and efficient design used in response surface modelling is the Box-Behnken design. In this study a $3^{3}$ Box-Behnken factorial design was employed to identify the factors (independent variables) having significant effect on the antibiotics Metronidazole and Sulfamethoxazole removal (dependent variables). The factors were selected and the ranges were further assigned based on our previous experience. Three factors, i.e. $\mathrm{pH}$, temperature and antibiotic concentration were chosen. Each independent variable was coded at three levels between -1 and +1 . The factors with their variation levels, are shown in Table 3. The experimental design used included 42 observations (randomized) - 12 factorial points (in triplicate) and six center points. The design of experiments matrix with the outcomes of experiments is shown in Table 4. The experimental data were fitted to a second-order model (Eq. (1)):(1)

where $y$ is the predicted response (antibiotic sorption capacity, $m g / g$ ), $x_{i}, x_{j}$ are the input variables (independent variables - $\mathrm{pH}$, temperature and antibiotic concentration) and $\beta$ denotes the regression coefficient - $\beta_{0}$ the intercept; $\beta_{\mathrm{i}}, \beta_{\mathrm{ii}}$ and $\beta_{\mathrm{ij}}$ are the coefficients for the linear, quadratic and interaction effects, respectively. JMP 5.01 (SAS Institute Inc., 
Cary, NC, USA) software was used to generate the matrix design, statistical analysis and regression models. The significance of the second-order models was evaluated by analysis of variance (ANOVA). The insignificant coefficients were eliminated and the final models were obtained.

Table 3. Independent variable levels and codified values for the Box-Behnken experimental design.

\begin{tabular}{lllll} 
Fator & \multicolumn{4}{c}{ Coded factor } \\
& & $-\mathbf{1}$ & $\mathbf{0}$ & $\mathbf{1}$ \\
$\mathbf{p H}$ & $\mathrm{X}_{1}$ & 2 & 5 & 8 \\
T $\left({ }^{\circ} \mathbf{C}\right)$ & $\mathrm{X}_{2}$ & 10 & 20 & 30 \\
Cin $(\mathbf{m g} / \mathbf{L})$ & $\mathrm{X}_{3}$ & 20 & 30 & 40
\end{tabular}

Table 4. Experimental Box-Behnken design matrix, measured ( $\left.\mathrm{q}_{\exp }\right)$ and predicted results $\left(q_{\text {mod }}\right)$.

\begin{tabular}{|c|c|c|c|c|c|c|}
\hline \multirow{2}{*}{ Rur } & \multicolumn{2}{|c|}{ Factors } & \multicolumn{2}{|c|}{ Metronidazole } & \multicolumn{2}{|c|}{ Sulfamethoxazole } \\
\hline & \multicolumn{6}{|c|}{ pH X $X_{1}$ T $\left({ }^{\circ} \mathrm{C}\right) X_{2} C_{\text {in }}(\mathrm{mg} / \mathrm{L}) X_{3} q_{\exp }(\mathrm{mg} / \mathrm{g}) q_{\bmod }(\mathrm{mg} / \mathrm{g}) q_{\exp }(\mathrm{mg} / \mathrm{g}) q_{\bmod }(\mathrm{mg} / \mathrm{g})$} \\
\hline \multirow{3}{*}{1} & & & 38.6 & & 57.2 & \\
\hline & 10 & 30 & 35.2 & 34.5 & 54.9 & 57.8 \\
\hline & & & 33.8 & & 54.3 & \\
\hline \multirow{3}{*}{2} & & & 38.0 & & 63.0 & \\
\hline & 20 & 20 & 33.2 & 35.4 & 60.3 & 62.3 \\
\hline & & & 39.3 & & 65.7 & \\
\hline \multirow{3}{*}{3} & & & 47.0 & & 81.2 & \\
\hline & 20 & 40 & 43.5 & 47.0 & 73.3 & 76.6 \\
\hline & & & 45.4 & & 79.0 & \\
\hline \multirow{3}{*}{4} & & & 50.7 & & 87.0 & \\
\hline & 30 & 30 & 43.4 & 47.9 & 79.3 & 80.4 \\
\hline & & & 46.3 & & 75.8 & \\
\hline 5 & 10 & 20 & 72.7 & 72.4 & 68.9 & 69.7 \\
\hline
\end{tabular}




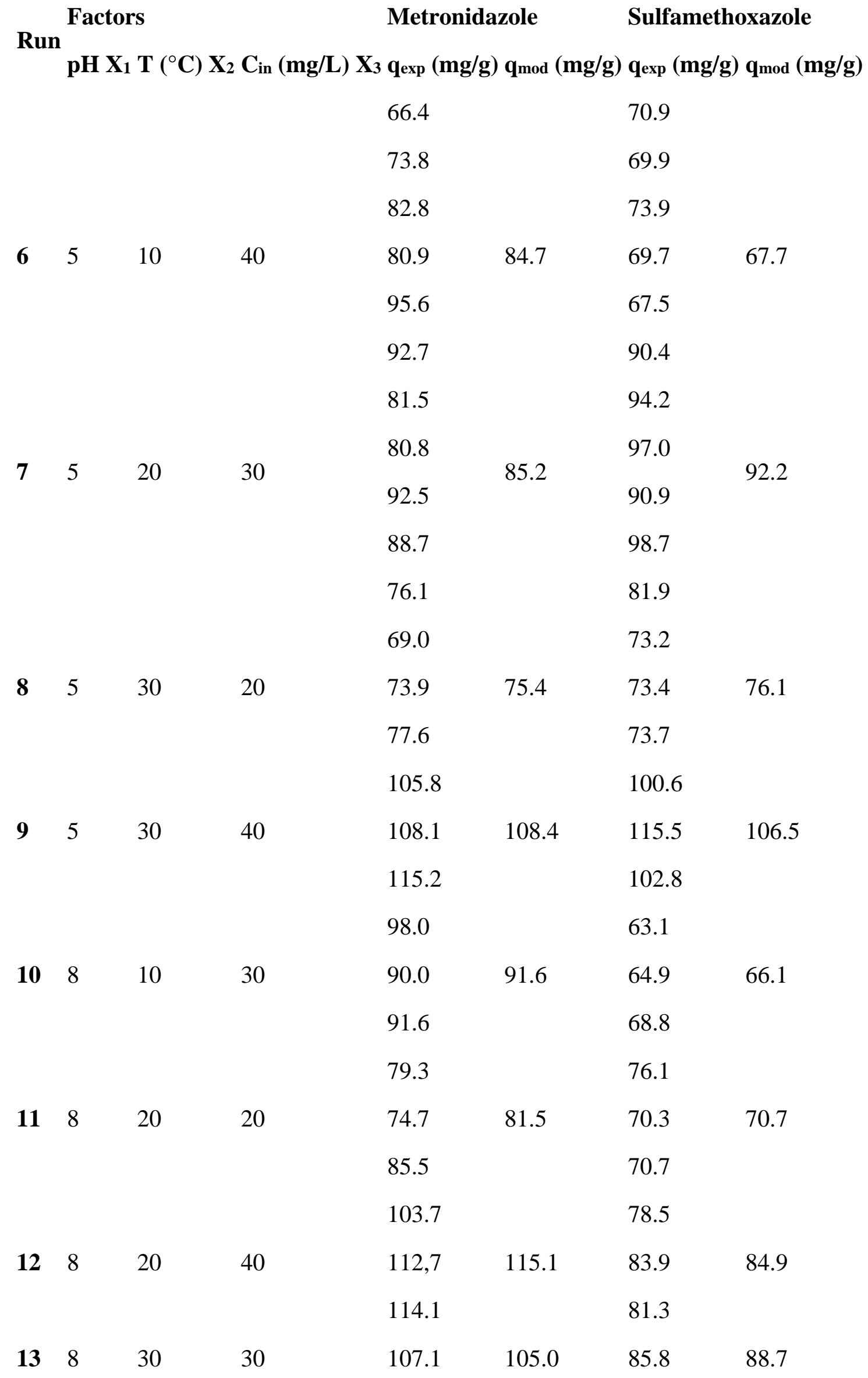




$\begin{array}{ccc}\text { Run } & \text { Metronidazole } & \text { Sulfamethoxazole } \\ \mathbf{p H} \mathbf{X}_{\mathbf{1}} \mathbf{T}\left({ }^{\circ} \mathbf{C}\right) \mathbf{X}_{\mathbf{2}} \mathbf{C} \mathbf{i n}(\mathbf{m g} / \mathbf{L}) \mathbf{X}_{\mathbf{3}} \mathbf{q} \mathbf{e x p}(\mathbf{m g} / \mathbf{g}) \mathbf{q} \mathbf{m o d}(\mathbf{m g} / \mathbf{g}) \mathbf{q} \exp (\mathbf{m g} / \mathbf{g}) \mathbf{q} \mathbf{m o d}(\mathbf{m g} / \mathbf{g}) & 94.9 \\ 110.0 & 93.1\end{array}$

\subsection{Analytical method}

Chromatographic analyses, for the individual antibiotics studied, were performed with a Merck Hitachi (Tokyo, Japan) system equipped with a L-7100 pump (Merck Hitachi), a Autosampler Model L-7250 (100 $\mu$ L loop) and a diode array detector L-7450 A (Merck Hitachi). Data was acquired and processed by HSM D-7000, version 3.1, software. A reversed-phase Purospher RP-18 endcapped column $(250 \mathrm{~mm} \times 4 \mathrm{~mm}$, particle size $5 \mu \mathrm{m})$ and a guard column Purospher RP-18e ( $4 \mathrm{~mm} \times 4 \mathrm{~mm}$ ) supplied by Merck (Darmstadt, Germany) were used. The method was based on a previously published methodology, with some modifications (Teixeira et al., 2008). The mobile phase consisted of a buffered aqueous solution (citrate buffer $20 \mathrm{mM}$ with $\mathrm{pH}$ adjusted to $2.50 \pm 0.02$ ) and acetonitrile (90:10 v/v; aqueous buffer:acetonitrile), at a flow-rate of $0.8 \mathrm{~mL} / \mathrm{min}$, for Metronidazole analysis. Sulfamethoxazole analysis was also performed in isocratic elution mode with a mobile phase consisted of a buffered aqueous solution (citrate buffer $20 \mathrm{mM}$ with $\mathrm{pH}$ adjusted to $2.50 \pm 0.02)$ and acetonitrile (75:25 v/v; aqueous buffer:acetonitrile), at a flow-rate of $0.8 \mathrm{~mL} / \mathrm{min}$. Injection volume was $100 \mu \mathrm{L}$ and the analyses (in triplicate) were performed at room temperature. Antibiotic identification was performed by comparison of standards, concerning retention time and UV spectra of the analyte. Detection was performed at 316 and $270 \mathrm{~nm}$ for Metronidazole and Sulfamethoxazole, respectively. Peak purity evaluation was also performed. Quantification was carried out using external calibration. Both methods were validated with all established calibration curves (in the range between 5 a $500 \mu \mathrm{g} / \mathrm{L}$ ) and characterized by high determination coefficients $\left(\mathrm{R}^{2}>0.999\right)$. The precision $(\mathrm{CV} \%)$, for both compounds, ranged from 0.3 to $8.5 \%$ and 0.6 to $10 \%$, for intra-assay and inter-assay conditions, respectively. Accuracy was estimated through analytical recovery tests in order to evaluate the suitability of the developed method for the determination of the target antibiotics in the aqueous matrices. Recovery ranged from 99.4 to $100.3 \%$.

\section{Results and discussion}


The great applicability of activated carbon in the removal of pollutants lies in a versatility that is considered unique and depends on the process and conditions employed and the raw material (precursor) from which it is produced. In addition to the high versatility these adsorbents are also distinguished by their high adsorption capacity due to their welldeveloped internal pore structure, surface area and the presence of a wide spectrum of surface functional groups. The main textural and chemical characteristics of the activated carbon are summarized in Table 1. Besides activated carbon properties, the ability to remove organic micro-pollutants depends on the solution chemistry (e.g. pH, ion strength and temperature), as well as the contaminant properties (e.g. water solubility, hydrophobicity, charge, polarizability, size, aromaticity and the presence of specific functional groups) (Moreno-Castilla, 2004; Rodríguez-Reinoso, 2001).

Metronidazole and Sulfamethoxazole are ionizable compounds and, depending on the $\mathrm{pH}$ of the medium, their neutral and ionized forms coexist in solution (Table 2). Removal of these species may, consequently, be significantly affected by $\mathrm{pH}$ and controlled by different mechanisms, possibly operating simultaneously.

\subsection{Response surface methodology (RSM) results}

The experimental conditions of the design, the results obtained $\left(\mathrm{q}_{\exp }\right)$ and predicted by the quadratic model ( $\mathrm{q}_{\mathrm{mod}}$ ) are given in Table 4 . A total of 42 observations (randomized) were performed for each antibiotic. Three replications were carried out for all design points and six to the center point. The experimental data were initially fitted to the complete second-order models (Eq. (1) ) and only the significant terms were maintained in the models (Table 5). The quality of the adjusted models was evaluated by means of determination coefficients, residues and lack-of-fit test obtained from the analysis of variance (ANOVA). The statistical significance of the models and of the coefficients was determined for a probability level of 5\%. The fitted quadratic models have determination coefficients higher than $91 \%$ and the lack-of-fit test indicate that the models are adequate ( $p$-value $\geq 0.05$ ). The ANOVA results showed that the quadratic models could be used to navigate the design space (further details can be found in the supplementary material). The quadratic equations (in coded factors) for Metronidazole and Sulfamethoxazole are given in Eqs. (2), (3), respectively:(2) 
Table 5. Fitted quadratic polynomial models.

\begin{tabular}{lllll} 
& \multicolumn{2}{l}{ Metronidazole } & \multicolumn{2}{c}{ Sulfamethoxazole } \\
& Coefficient $\boldsymbol{p}$-Value Coefficient $\boldsymbol{p}$-Value \\
$\boldsymbol{\beta}_{\mathbf{0}}$ & $85.2 \pm 2.5$ & $3.6 \mathrm{E}-39$ & $92.2 \pm 3.7$ & $1.6 \mathrm{E}-33$ \\
$\boldsymbol{\beta}_{1}$ & $28.6 \pm 2.2$ & $5.0 \mathrm{E}-25$ & $4.2 \pm 1.9$ & $6.2 \mathrm{E}-05$ \\
$\boldsymbol{\beta}_{2}$ & $6.7 \pm 2.2$ & $2.8 \mathrm{E}-07$ & $11.3 \pm 1.9$ & $4.2 \mathrm{E}-14$ \\
$\boldsymbol{\beta}_{3}$ & $11.3 \pm 2.2$ & $1.4 \mathrm{E}-12$ & $7.1 \pm 1.9$ & $4.6 \mathrm{E}-09$ \\
$\boldsymbol{\beta}_{12}$ & n.s. -1 & & n.s. & \\
$\boldsymbol{\beta}_{13}$ & $5.5 \pm 3.0$ & $8.3 \mathrm{E}-04$ & n.s. & \\
$\boldsymbol{\beta}_{23}$ & $5.2 \pm 3.0$ & $1.4 \mathrm{E}-03$ & $8.1 \pm 2.6$ & $4.0 \mathrm{E}-07$ \\
$\boldsymbol{\beta}_{11}$ & $-15.5 \pm 3.3$ & $2.6 \mathrm{E}-11$ & $-12.7 \pm 2.9$ & $3.2 \mathrm{E}-10$ \\
$\boldsymbol{\beta}_{22}$ & n.s. & & $-6.3 \pm 2.9$ & $1.3 \mathrm{E}-04$ \\
$\boldsymbol{\beta}_{33}$ & n.s. & & $-5.9 \pm 2.9$ & $2.5 \mathrm{E}-04$ \\
$\mathbf{R}^{2}$ & 0.9662 & & 0.9137 & \\
Lack-of-fit $\boldsymbol{p}$-value & 0.22 & 0.25 &
\end{tabular}

a

Not significant (95\%).

\subsection{Response surface methodology (RSM) analysis - factor influence}

The three-dimensional response surfaces (with one variable kept constant and varying the other two variables within the experimental range) are shown in Fig. 1, Fig. 2. 

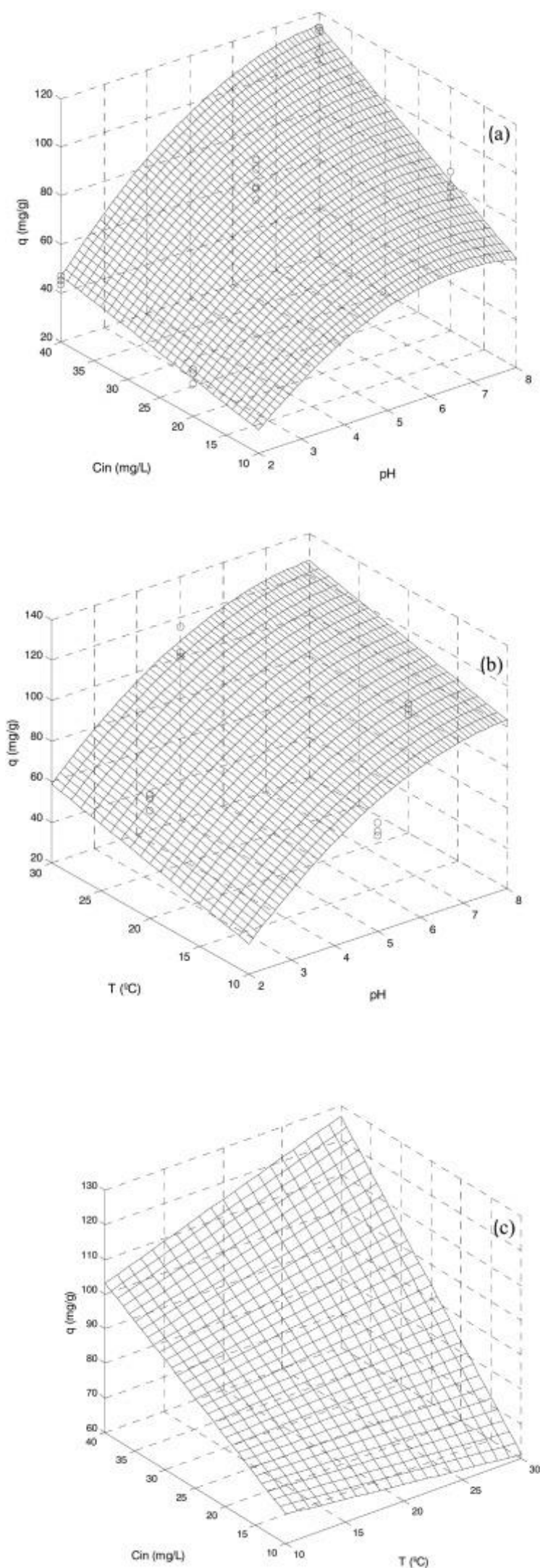

Fig. 1. Response surface plot for Metronidazole: (a) initial concentration vs $\mathrm{pH}$ at $20^{\circ} \mathrm{C}$; (b) temperature vs $\mathrm{pH}$ for $\mathrm{C}_{\mathrm{in}}=40 \mathrm{mg} / \mathrm{L}$; (c) initial concentration vs temperature for $\mathrm{pH}=6$. 

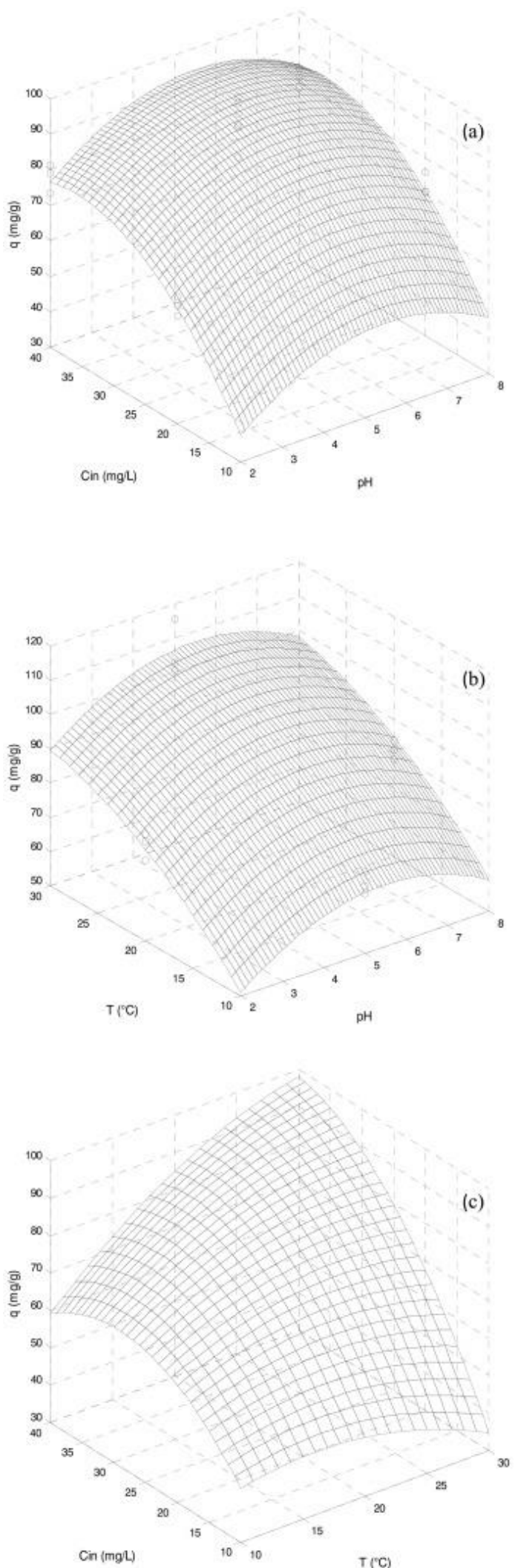

Fig. 2. Response surface plot for Sulfamethoxazole: (a) initial concentration vs $\mathrm{pH}$ at $20^{\circ} \mathrm{C}$; (b) temperature vs $\mathrm{pH}$ for $\mathrm{C}_{\mathrm{in}}=40 \mathrm{mg} / \mathrm{L}$; (c) initial concentration vs temperature for $\mathrm{pH}=6$. 
The predicted values for the responses range from 34.5 to $115.1 \mathrm{mg} / \mathrm{g}$ and from 57.8 to $106.7 \mathrm{mg} / \mathrm{g}$ for Metronidazole and Sulfamethoxazole, respectively (Table 4).

The linear terms are, for the three independent variables $\mathrm{pH}, \mathrm{T}$ and $\mathrm{C}_{\mathrm{in}}$, significant for both models. Only the quadratic effect of $\mathrm{pH}$ has a significant influence on the response observed for the antibiotic Metronidazole, whereas all quadratic terms are significant in the model adjusted to the data obtained for Sulfamethoxazole. The $\mathrm{pH}$ (linear effect) is, in the case of the antibiotic Metronidazole, the parameter that had the greatest influence on the adsorbed amount. For the antibiotic Sulfamethoxazole, it is the temperature (linear effect) that has the greatest influence on the amount adsorbed.

The results concerning the adsorption of the antibiotic Metronidazole (Fig. 1) unequivocally show that the conditions that maximize the response coincide with the maximum levels assigned to the factors. The predicted value for the adsorbed amount is, under these conditions $\left(\mathrm{pH}=8, \mathrm{C}_{\mathrm{in}}=40 \mathrm{mg} / \mathrm{L}, T=30^{\circ} \mathrm{C}\right)$, of $127 \mathrm{mg} / \mathrm{g}$. It is interesting to note, in particular, the behaviour of the response as a function of the $\mathrm{pH}$ and the temperature. The increase of these two variables always led to an increase in adsorption capacity. Thus, it is not possible to determine the optimum conditions within the range studied, higher values of temperature and in particular of $\mathrm{pH}$ might lead to higher removals but are, however, less probable operating conditions. The $\mathrm{pH}$ influence is even more evident when, for example, by setting the temperature at $20^{\circ} \mathrm{C}$ and considering the maximum concentration $\left(C_{i n}=40 \mathrm{mg} / \mathrm{L}\right)$, a variation in the adsorbed amount of $47 \mathrm{mg} / \mathrm{g}$ to $115 \mathrm{mg} / \mathrm{g}$ is expected for a $\mathrm{pH}$ variation between 2 and 8 (Fig. 1).

For $\mathrm{pH}$ values equal to or $>6$ the adsorption capacity (predicted) is higher than $105 \mathrm{mg} / \mathrm{g}$. The model predicts, for a variation of 2 units in the $\mathrm{pH}$ value (from 6 to 8 ), an increase of approximately $10 \mathrm{mg}$ in the adsorption capacity. A variation from 94 to $118 \mathrm{mg} / \mathrm{g}$ is predicted for the adsorption capacity when a change in temperature occurs in the range of 10 to $30^{\circ} \mathrm{C}$ (at $\mathrm{pH} 6$ and $\mathrm{C}_{\mathrm{in}}=40 \mathrm{mg} / \mathrm{L}$ ).

The best conditions, predicted by the model, for the removal of Sulfamethoxazole were the following: a value of 5.5 for $\mathrm{pH}$ (within the variation range selected for this factor), a temperature of $30{ }^{\circ} \mathrm{C}$ and an antibiotic concentration of $40 \mathrm{mg} / \mathrm{L}$ (i.e. the upper limits of both variables ranges). For these conditions the predicted value is $106.9 \mathrm{mg} / \mathrm{g}$. The influence of temperature on the adsorption capacity of this antibiotic is, in the studied 
range, slightly more expressive than that observed for the $\mathrm{pH}$. The model predicts, at $\mathrm{pH} 6$ a variation between 67.7 and $106.5 \mathrm{mg} / \mathrm{g}$ for a temperature increase in the range of 10 to $30^{\circ} \mathrm{C}$.

Similarly, to what had been observed for the antibiotic Metronidazole, the value that maximizes the response, for the parameter temperature, coincides with the maximum set for this variable. These are therefore conditions that maximize the response but not necessarily the optimum conditions and it is possible that higher values can be achieved. This would imply carrying out a new set of tests where higher temperatures than those studied, should be considered but which do not appear to be particularly relevant from a practical point of view. Different behaviour is, however, observed for the $\mathrm{pH}$ parameter. The optimum value clearly lies within the selected range of variation and it is interesting to verify the existence of a range of values for which the adsorption capacity displays very close values (Fig. 2). A pH range of approximately 4.6 to 7.2 will lead to a response variation ( $\mathrm{q}_{\mathrm{mod}}$ ) of 90 to $94 \mathrm{mg} / \mathrm{g}$, i.e. $\sim 4 \mathrm{mg} / \mathrm{g}$, (at $20^{\circ} \mathrm{C}$ ). Similar behaviour is observed for the tests performed at 10 and $30^{\circ} \mathrm{C}$. The removal of Sulfamethoxazole appears to have a $\mathrm{pH}$ range for which the adsorption capacity remains almost independent of this parameter.

Overall the models predict a maximum capacity $>100 \mathrm{mg} / \mathrm{g}$ for both compound (127 mg/g and $107 \mathrm{mg} / \mathrm{g}$ for Metronidazole and Sulfamethoxazole respectively).

The results highlight the influence of the $\mathrm{pH}$ on the amount adsorbed for both antibiotics, but the range of $\mathrm{pH}$ values that maximize the responses are different. While the removal of Metronidazole is favoured by increasing values of $\mathrm{pH}$, coinciding the maximum value with the upper limit of the study domain $(\mathrm{pH} 8)$, Sulfamethoxazole presents a maximum value around 5.5, displaying a decrease in the extent of adsorption as the $\mathrm{pH}$ increases.

The results appear to be linked to both the carbon surface charge and the antibiotic speciation. Both Metronidazole and Sulfamethoxazole are ionizable compounds and, depending on the $\mathrm{pH}$ of the medium, their neutral and ionized forms coexist in solution (Table 1). For the typical/common wastewaters $\mathrm{pH}$ conditions, Metronidazole will be present in its non-ionized form while Sulfamethoxazole will exhibit considerable variation in its speciation. Being an amphoteric substance, Sulfamethoxazole may exist in its neutral and ionized form, positively or negatively. Thus, at $\mathrm{pH}$ values between 5.60 
and $1.85\left(\mathrm{pK}_{\mathrm{a} 1}<\mathrm{pH}<\mathrm{pK}_{\mathrm{a} 2}\right)$ the neutral form will predominate while at $\mathrm{pH}$ values $>5.60$ $\left(\mathrm{pH}>\mathrm{pK}_{\mathrm{a} 2}\right)$ the anionic species will be dominant.

For the lowest value evaluated ( $\mathrm{pH} 2)$ the cationic form of Metronidazole will predominate in solution $(\sim 80 \%)$, decreasing as the $\mathrm{pH}$ increases; at $\mathrm{pH} \sim 4.5$ the antibiotic will be mainly in its molecular form $(\sim 100 \%)$. The $\mathrm{pH}$ also influences the solubility (and hydrophobicity) of the antibiotic, whose maximum value under the conditions of this study coincided with the lowest $\mathrm{pH}$ studied and decreases with increasing $\mathrm{pH}$ (as the cationic form decreases in solution) (Rediguieri et al., 2011; Wu and Fassihi, 2005). Thus, it is not surprising, that the lower uptake occurs at $\mathrm{pH} 2$, since this are conditions for which the activated carbon has a higher density of positive charges $\left(\mathrm{pH}_{\text {solution }}<\mathrm{pH}\right.$ pzc $)$ and the cationic species predominates in solution. As the $\mathrm{pH}$ increases the electrostatic repulsion decreases and an increase in the adsorbed amount is expected. Similar results for Metronidazole sorption as a function of $\mathrm{pH}$ were reported in some recently published studies (Ocampo-Pérez et al., 2013; Rivera-Utrilla et al., 2010).

For the antibiotic Sulfamethoxazole, the lowest adsorbed amount is also observed at pH 2. Both the activated carbon surface $\left(\mathrm{pH}_{\text {solution }}>\mathrm{pH}_{\mathrm{pzc}}\right)$ and antibiotic are positively (cationic form represents $\sim 41 \%$ ) charged and the removal became less favourable due to the electrostatic repulsion. At $\mathrm{pH} 4$ approximately $96 \%$ of the antibiotic will be on a neutral form while in the $\mathrm{pH}$ range between 4 and 3 sulfamethoxazole exists mainly in the neutral form (>90\%), with an isoelectric point around 3.7. At pH 5 the neutral form ( 80\%) will predominate in solution (with the anionic form corresponding to $\sim 20 \%$ ) while at $\mathrm{pH} 6$ the anionic form will account for $\sim 72 \%$ and neutral $\sim 28 \%$. As already mentioned, $\mathrm{pH}$ values around the $\mathrm{pH}_{\mathrm{pzc}}$ maximize the removal of this antibiotic. At $\mathrm{pH} 6$ the activated carbon surface will display global zero charge $\left(\mathrm{pH}_{\text {solution }} \sim \mathrm{pH}_{\mathrm{pzc}}\right)$ and therefore, the electrostatic repulsions will be at their minimum. The subsequent increase in the solution $\mathrm{pH}$ will led to a decrease in the Sulfamethoxazole removal. The carbon surface will be negatively charged $\left(\mathrm{pH}_{\text {solution }}>\mathrm{pH}_{\mathrm{pzc}}\right)$ and the anionic form will also increase in solution. As a result, repulsive interactions will be established between the carbon surface and the negatively charged antibiotic (dominant in solution). Moreover, the anionic form of Sulfamethoxazole is also the most soluble and hydrophilic (Carda-Broch and Berthod, 2004). Similar results on $\mathrm{pH}$ influence have been reported in the literature for the 
antibiotic Sulfamethoxazole (Gao and Pedersen, 2005; Ji et al., 2009; Yang et al., 2011; Zhang et al., 2010).

Overall, the results suggest that $\mathrm{pH}$ values near the point of zero charge might constitute a good compromise in the removal of these two compounds.

For $\mathrm{pH}$ values around $\mathrm{pH}_{\mathrm{pzc}}$, i.e. values $\sim 6$, the models predict (at $20^{\circ} \mathrm{C}$ and concentration of $40 \mathrm{mg} / \mathrm{L}$ ) to Metronidazole a sorption capacity of $106 \mathrm{mg} / \mathrm{g}$ and $94 \mathrm{mg} / \mathrm{g}$ to Sulfamethoxazole. These values were experimentally validated. Langmuir (Eq. (4)) and Freundlich (Eq. (5)) isotherms were applied to the experimental adsorption data (in single solution solute) for both compounds at $\mathrm{pH} 6$ and $20^{\circ} \mathrm{C}:(4)$

where $\mathrm{Q}_{\mathrm{L}}$ is maximum adsorption capacity $(\mathrm{mg} / \mathrm{g})$ corresponding to a monolayer coverage, $\mathrm{K}_{\mathrm{L}}$ is the adsorption equilibrium constant $(\mathrm{L} / \mathrm{mg})$ and $\mathrm{C}_{\mathrm{eq}}$ is the equilibrium concentration $(\mathrm{mg} / \mathrm{L})$ in the aqueous phase.(5)

where $\mathrm{C}_{\mathrm{eq}}$ is the equilibrium concentration $(\mathrm{mg} / \mathrm{L})$ in the aqueous phase, $\mathrm{K}_{\mathrm{F}}$ $\left(\left(\mathrm{mg} / \mathrm{g} /(\mathrm{mg} / \mathrm{L})^{1 / \mathrm{nF}}\right)\right)$ and $\mathrm{n}_{\mathrm{F}}$ (dimensionless) are model parameters related to the adsorption capacity and adsorption intensity, respectively. Experimental results were fitted to Eqs. (4), (5) by nonlinear regression (JMP 5.0.1 software) and are summarized in Table 6 .

Table 6. Equilibrium isotherms modelling: parameters and statistical data $(F$-test).

\section{Langmuir}

QL $(\mathrm{mg} / \mathrm{g})$

$107.4 \pm 4$

Metronidazole

$$
9
$$$$
2.6 \pm 0.7 \begin{array}{ll}
0.979 \\
9
\end{array} 60.8 \pm 5.2
$$

Sulfamethoxazo

le

$$
93.5 \pm 3.8 \begin{array}{lll}
22.2 \pm 5 . & 0.972 & 65.0 \pm 6.7 \\
6 & 4 &
\end{array}
$$

\section{Freundlich}

$\mathbf{K}_{\mathbf{F}}$ $\left(\mathrm{mg} / \mathrm{g} /(\mathrm{mg} / \mathrm{L})^{1 /} \mathrm{nF}_{\mathrm{F}}\right.$

$\mathbf{R}^{2}$ $\mathbf{F}_{\mathrm{cal}} / \mathbf{F}_{\text {tab }}$ ) $4.5 \pm 0.0 .9292 .65 / 5.8$ $7 \quad 6 \quad 2$ $5.5 \pm 1.0 .8395 .18 / 5.8$ $2 \quad 4 \quad 2$

The determination coefficient suggest that a better fit is obtained to the Langmuir model. The Freundlich model showed higher deviations in the representation of the experimental data, i.e. highest differences between the fitted values $\left(\mathrm{q}_{\mathrm{mod}}\right)$ and the experimental values 
( $\mathrm{q}_{\mathrm{exp}}$ ), which can also be confirmed by the visual inspection of the isotherms (Fig. 3). However, the F-test indicated the models are not statistically different. The value of $\mathrm{F}_{\mathrm{cal}}$, calculated as the ratio between the variances of the two models, was below the tabulated F-value for $95 \%$ confidence level, though marginally for Sulfamethoxazole.

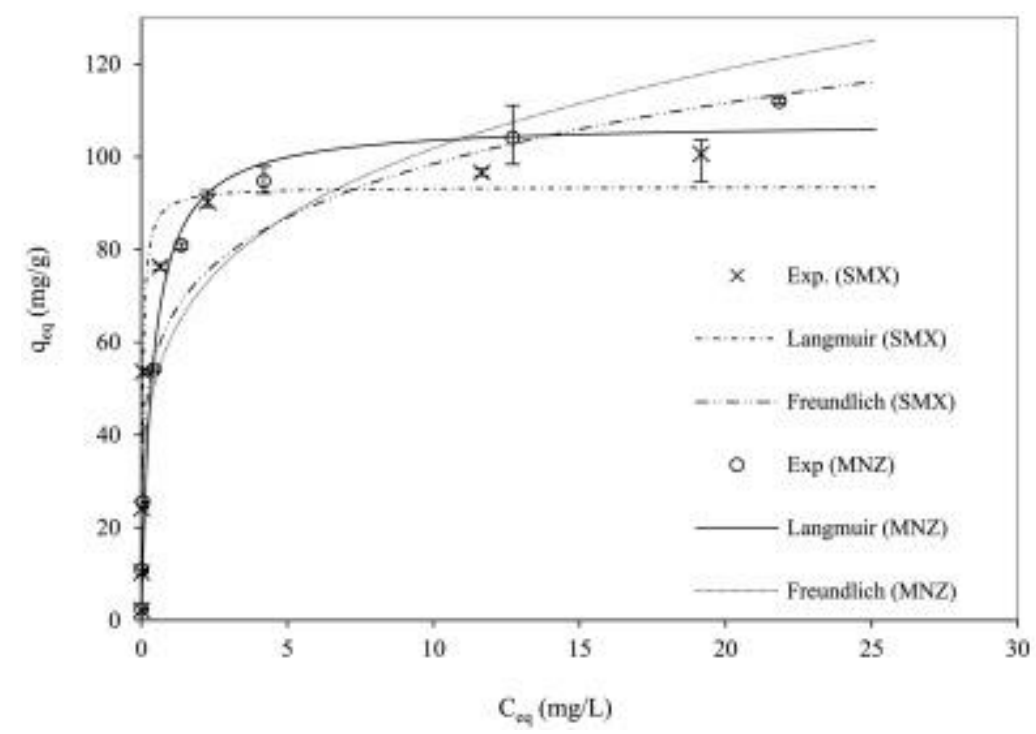

Fig. 3. Antibiotics adsorption isotherms at $20^{\circ} \mathrm{C}$ and $\mathrm{pH} 6-$ Metronidazole (MNZ); Sulfamethoxazole (SMX).

The analysis of the equilibrium data confirms what the optimization studies already indicated, that is, a somewhat higher sorption capacity for the antibiotic Metronidazole. The difference is not expressive, a maximum capacity of $107.4 \mathrm{mg} / \mathrm{g}$ is expected for Metronidazole compared to $93.5 \mathrm{mg} / \mathrm{g}$ for Sulfamethoxazole. However, the data indicate an affinity for the adsorbent significantly higher for the antibiotic Sulfamethoxazole, as can be seen from the values obtained for the Langmuir constant. The higher affinity is also perceptible in the graphical representation of the isotherms (Fig. 3), through the slope of the tangent to the isotherm when the equilibrium concentration tends to zero. This is an important feature as it shows an effective removal for low initial concentrations.

Sorption capacities ranging from 46 to $241 \mathrm{mg} / \mathrm{g}$ (pH 6 and $25^{\circ} \mathrm{C}$ ) for activated carbon have recently been reported for the removal of Metronidazole (Carrales-Alvarado et al., 2014). For Sulfamethoxazole at $\mathrm{pH}$, sorption capacities of 11 and $25 \mathrm{mg} / \mathrm{g}$ were observed in activated carbon ( $\mathrm{Ji}$ et al., 2009). 
As mentioned before, the adsorption capacity depends on the nature of the activated carbon (textural/morphological and chemical characteristics), and solutes (solubility, hydrophobicity, functional groups and molecular dimensions). Although lower solubility and/or higher hydrophobicity is expected to translate into greater affinity for the solid matrix and lead to better removal capabilities, contradictory trends are often observed when using these parameters in the analysis of the removal of various compounds. Additionally, the nature of the functional groups of the solutes, by affecting the electronic density of the aromatic/heterocyclic rings, influences also the interactions with the matrix of the adsorbent. The interpretation of the differences in affinity of the solutes has constituted, for these reasons, a complex matter.

As above-mentioned, the $\mathrm{pH}$ has a strong influence on the speciation, solubility and hydrophobicity of the two antibiotics. At pH 6, Metronidazole is in solution only in its neutral form, with the lowest value for solubility and the highest for hydrophobicity; Sulfamethoxazole, because of its speciation (at $\mathrm{pH} 6$ the anionic form represents $\sim 72 \%$ and the neutral $\sim 28 \%$ ) is more soluble and much less hydrophobic. However, the observed trend may also be related to the size of antibiotics. For organic compounds having rings of aromatic nature the adsorption occurs, preferably, with a parallel orientation to the surface of the basal plane. This orientation increases the contact surface between the aromatic rings by maximizing the interactions. The higher size of Sulfamethoxazole and particularly its non-planarity may justify the lower adsorption capacity despite the higher affinity it has for the activated carbon surface.

\section{Conclusion}

Adsorption extent of organic compounds is known to depend strongly on the intrinsic properties of the adsorbent/adsorbate pair. However, it can be also significantly influenced by the operating conditions such as: temperature, $\mathrm{pH}$, ionic strength, presence of other species in solution, contact time, etc. In this work, the influence of the $\mathrm{pH}$, temperature, and the antibiotic initial concentration in the extent of the adsorption, was evaluated. A Box-Behnken design with response surface methodology was applied to examine the role of the three factors on Metronidazole and Sulfamethoxazole removal. Mathematical models were developed for each antibiotic showing the effect of each factor and their interactions on the adsorbed amount. The observed $\mathrm{pH}$-dependent adsorption 
can be explained by considering the activated carbon $\mathrm{pH}_{\mathrm{pzc}}$ and the antibiotic speciation. The adsorption equilibrium is well described by the Langmuir model. The maximum sorption capacity, predicted by the Langmuir model, is $107.4 \mathrm{mg} / \mathrm{g}$ for Metronidazole and $93.5 \mathrm{mg} / \mathrm{g}$ for Sulfamethoxazole, in agreement with data from the experimental design. The results suggest that $\mathrm{pH}$ values around the activated carbon $\mathrm{pH}_{\mathrm{pzc}}$ might represent a good compromise in the removal of both compounds. The walnut shell based activated carbon showed, however, good removal efficiency over a large $\mathrm{pH}$ range. Moreover, waste based activated carbons might represent valuable options, due to the increased demand for ACs.

\section{Acknowledgments}

This work was financially supported by the projects POCI-01-0145-FEDER-006939 (LEPABE), POCI-010145-FEDER-007265 (REQUIMTE/LAQV) funded by the European Regional Development Fund (ERDF), through COMPETE2020 - Programa Operacional Competitividade e Internacionalização (POCI) and by national funds, through FCT - Fundação para a Ciência e a Tecnologia (LEPABE UID/EQU/00511/2013; REQUIMTE/LAQV - UID/QUI/50006/2013) and NORTE-010145-FEDER-000005 - LEPABE-2-ECO-INNOVATION, supported by North Portugal Regional Operational Programme (NORTE 2020), under the Portugal 2020 Partnership Agreement, through the European Regional Development Fund (ERDF).

\section{References}

Arpin-Pont et al., 2016

L. Arpin-Pont, M.J.M. Bueno, E. Gomez, H. FenetOccurrence of PPCPs in the marine environment: a review

Environ. Sci. Pollut. Res., 23 (2016), pp. 4978-4991, 10.1007/s11356-014-3617$\underline{\mathrm{x}}$

Carda-Broch and Berthod, 2004

S. Carda-Broch, A. BerthodCountercurrent chromatography for the measurement of the hydrophobicity of sulfonamide amphoteric compounds Chromatographia, 59 (2004), pp. 79-87, 10.1365/s10337-003-0140-5 
Carrales-Alvarado et al., 2014

D.H. Carrales-Alvarado, R. Ocampo-Pérez, R. Leyva-Ramos, J. RiveraUtrillaRemoval of the antibiotic metronidazole by adsorption on various carbon materials from aqueous phase

J. Colloid Interface Sci., 436C (2014), pp. 276-285, 10.1016/j.jcis.2014.08.023

Carvalho and Santos, 2016

I.T. Carvalho, L. SantosAntibiotics in the aquatic environments: a review of the European scenario

Environ. Int., 94 (2016), pp. 736-757, 10.1016/J.ENVINT.2016.06.025

Coutu et al., 2013

S. Coutu, V. Wyrsch, H.K. Wynn, L. Rossi, D.A. BarryTemporal dynamics of antibiotics in wastewater treatment plant influent

Sci. Total Environ., 458-460 (2013), pp. 20-26, 10.1016/j.scitotenv.2013.04.017

Davis et al., 2006

J.L. Davis, D. Little, A.T. Blikslager, M.G. PapichMucosal permeability of water-soluble drugs in the equine jejunum: a preliminary investigation

J. Vet. Pharmacol. Ther., 29 (2006), pp. 379-385

Dean and Voss, 1999

A. Dean, D. VossDesign and Analysis of Experiments

Springer-Verlag, New York (1999)

$\underline{\text { Ferro-García et al., } 1998}$

M.A. Ferro-García, J. Rivera-Utrilla, I. Bautista-Toledo, C. MorenoCastillaAdsorption of humic substances on activated carbon from aqueous solutions and their effect on the removal of $\mathrm{Cr}$ (III) ions

Langmuir, 14 (1998), pp. 1880-1886, 10.1021/la970565h 
Flores-Cano et al., 2016

J.V. Flores-Cano, M. Sánchez-Polo, J. Messoud, I. Velo-Gala, R. Ocampo-Pérez,

J. Rivera-UtrillaOverall adsorption rate of metronidazole, dimetridazole and diatrizoate on activated carbons prepared from coffee residues and almond shells

J. Environ. Manag., 169 (2016), pp. 116-125, 10.1016/j.jenvman.2015.12.001

Haghseresht et al., 2001

F. Haghseresht, S. Nouri, G.Q. LuEffects of the solute ionization on the adsorption of aromatic compounds from dilute aqueous solutions by activated carbon

Langmuir, 18 (2001), pp. 1574-1579

Gao and Pedersen, 2005

J. Gao, J. a PedersenAdsorption of sulfonamide antimicrobial agents to clay minerals

Environ. Sci. Technol., 39 (2005), pp. 9509-9516

Gros et al., 2012

M. Gros, M. Petrovic, A. GinebredaEmerging and priority pollutants in rivers

H. Guasch, A. Ginebreda, A. Geiszinger (Eds.), Emerging and Priority Pollutants in Rivers, The Handbook of Environmental Chemistry, Springer Berlin Heidelberg, Berlin, Heidelberg (2012), pp. 1-24, 10.1007/978-3-642-25722-3

Gupta et al., 2009

V.K. Gupta, P.J.M. Carrott, M.M.L. Ribeiro CarrottLow-cost adsorbents: growing approach to wastewater treatment - a review

Crit. Rev. Environ. Sci. Technol., 39 (2009), pp. 783-842, $\underline{10.1080 / 10643380801977610}$

$\underline{\text { Homem and Santos, } 2011}$

V. Homem, L. SantosDegradation and removal methods of antibiotics from aqueous matrices-a review

J. Environ. Manag., 92 (2011), pp. 2304-2347, 10.1016/j.jenvman.2011.05.023 
$\underline{\mathrm{Hu} \text { and Vansant, } 1995}$

Z. Hu, E.F. VansantSynthesis and characterization of a controlled-microporesize carbonaceous adsorbent produced from walnut shell

Microporous Mater., 3 (1995), pp. 603-612

$\underline{\text { Article }}$

Huerta et al., 2013

B. Huerta, E. Marti, M. Gros, P. López, M. Pompêo, J. Armengol, D. Barceló, J.L. Balcázar, S. Rodríguez-Mozaz, R. MarcéExploring the links between antibiotic occurrence, antibiotic resistance, and bacterial communities in water supply reservoirs

Sci. Total Environ., 456-457 (2013), pp. 161-170, 10.1016/j.scitotenv.2013.03.071

$\underline{\text { Article }}$

$\underline{\text { Ji et al., } 2009}$

L. Ji, W. Chen, S. Zheng, Z. Xu, D. ZhuAdsorption of sulfonamide antibiotics to multiwalled carbon nanotubes

Langmuir, 25 (2009), pp. 11608-11613, 10.1021/la9015838

Jones et al., 2005

H. Jones, O.A., N. Voulvoulis, J.N. LesterHuman pharmaceuticals in wastewater treatment processes

Crit. Rev. Environ. Sci. Technol., 35 (2005), pp. 401-427, $\underline{10.1080 / 10643380590956966}$

$\underline{\text { Joss et al., } 2008}$

A. Joss, H. Siegrist, T.A. TernesAre we about to upgrade wastewater treatment for removing organic micropollutants?

Water Sci. Technol., 57 (2008), pp. 251-255, 10.2166/wst.2008.825 
$\underline{\text { Kasprzyk-Hordern et al., } 2009}$

B. Kasprzyk-Hordern, R.M. Dinsdale, A.J. GuwyThe removal of pharmaceuticals, personal care products, endocrine disruptors and illicit drugs during wastewater treatment and its impact on the quality of receiving waters

Water Res., 43 (2009), pp. 363-380, 10.1016/j.watres.2008.10.047

$\underline{\text { Khetan and Collins, } 2007}$

S.K. Khetan, T.J. CollinsHuman pharmaceuticals in the aquatic environment: a challenge to green chemistry

Chem. Rev., 107 (2007), pp. 2319-2364, 10.1021/cr020441w

$\underline{\text { Kim et al., } 2001}$

J.W. Kim, M.H. Sohn, D.S. Kim, S.M. Sohn, Y.S. KwonProduction of granular activated carbon from waste walnut shell and its adsorption characteristics for $\mathrm{Cu}(2+)$ ion

J. Hazard. Mater., 85 (2001), pp. 301-315

Kovalova et al., 2012

L. Kovalova, H. Siegrist, H. Singer, A. Wittmer, C.S. Mcardell, S. PageSupporting Information for: Hospital Wastewater Treatment by Membrane Bioreactor: Performance and Efficiency for Organic Micropollutant Elimination

(2012)

$\underline{\text { Kovalova et al., } 2013}$

L. Kovalova, H. Siegrist, U. Von Gunten, J. Eugster, M. Hagenbuch, A. Wittmer, R. Moser, C.S. McardellElimination of micropollutants during post-treatment of hospital wastewater with powdered activated carbon, ozone, and UV Environ. Sci. Technol., 47 (2013), pp. 7899-7908

$\underline{\text { Kümmerer, 2009a }}$

K. KümmererAntibiotics in the aquatic environment-a review-part I

Chemosphere, 75 (2009), pp. 417-434, 10.1016/j.chemosphere.2008.11.086। 
Kümmerer, 2009b

K. KümmererAntibiotics in the aquatic environment - a review - part II Chemosphere, 75 (2009), pp. 435-441, 10.1016/j.chemosphere.2008.12.006

Lindberg et al., 2004

R. Lindberg, P.-A. Jarnheimer, B. Olsen, M. Johansson, M. TysklindDetermination of antibiotic substances in hospital sewage water using solid phase extraction and liquid chromatography/mass spectrometry and group analogue internal standards

Chemosphere, 57 (2004), pp. 1479-1488, 10.1016/j.chemosphere.2004.09.015

Loos et al., 2009

R. Loos, B.M. Gawlik, G. Locoro, E. Rimaviciute, S. Contini, G. BidoglioEUwide survey of polar organic persistent pollutants in European river waters Environ. Pollut., 157 (2009), pp. 561-568, 10.1016/j.envpol.2008.09.020

$\underline{\text { Loos et al., } 2010}$

R. Loos, G. Locoro, S. Comero, S. Contini, D. Schwesig, F. Werres, P. Balsaa, O. Gans, S. Weiss, L. Blaha, M. Bolchi, B.M. GawlikPan-European survey on the occurrence of selected polar organic persistent pollutants in ground water Water Res., 44 (2010), pp. 4115-4126, 10.1016/j.watres.2010.05.032

$\underline{\text { Loos et al., } 2012}$

R. Loos, R. Carvalho, S. Comero, D.C. António, M. Ghiani, T. Lettieri, G. Locoro, B. Paracchini, S. Tavazzi, B.M. Gawlik, S. Voorspoels, D. SchwesigEU wide monitoring survey on waste water treatment plant effluents

Luxembourg (2012), 10.2788/60663

\section{López-Serna et al., 2013}

R. López-Serna, A. Jurado, E. Vázquez-Suñé, J. Carrera, M. Petrovic, D. BarcelóOccurrence of 95 pharmaceuticals and transformation products in urban groundwaters underlying the metropolis of Barcelona, Spain Environ. Pollut., 174 (2013), pp. 305-315, 10.1016/j.envpol.2012.11.022 
Margot et al., 2013

J. Margot, C. Kienle, A. Magnet, M. Weil, L. Rossi, L.F. Alencastro, C. Abegglen, D. Thonney, N. Chèvref, M. Schärer, D.A. BarryTreatment of micropollutants in municipal wastewater: ozone or powdered activated carbon?

Sci. Total Environ., 461-462 (2013), pp. 480-498

Martínez et al., 2003

F. Martínez, C.M. Ávila, A. GómezThermodynamic study of the solubility of some sulfonamides in cyclohexane

J. Braz. Chem. Soc., 14 (2003), pp. 803-808

Martínez et al., 2006

M.L. Martínez, M.M. Torres, C.a. Guzmán, D.M. MaestriPreparation and characteristics of activated carbon from olive stones and walnut shells Ind. Crop. Prod., 23 (2006), pp. 23-28, 10.1016/j.indcrop.2005.03.001

Moreno-Castilla, 2004

C. Moreno-CastillaAdsorption of organic molecules from aqueous solutions on carbon materials

Carbon N. Y., 42 (2004), pp. 83-94, 10.1016/j.carbon.2003.09.022

\section{Ocampo-Pérez et al., 2013}

R. Ocampo-Pérez, F. Orellana-Garcia, M. Sánchez-Polo, J. Rivera-Utrilla, I. Velo-Gala, M.V. López-Ramón, M.A. Alvarez-MerinoNitroimidazoles adsorption on activated carbon cloth from aqueous solution

J. Colloid Interface Sci., 401 (2013), pp. 116-124, 10.1016/j.jcis.2013.03.038

Paíga et al., 2016

P. Paíga, L.H.M.L.M. Santos, S. Ramos, S. Jorge, J.G. Silva, C. DelerueMatosPresence of pharmaceuticals in the Lis river (Portugal): sources, fate and seasonal variation

Sci. Total Environ., 573 (2016), pp. 164-177, 10.1016/j.scitotenv.2016.08.089 
M. Papageorgiou, C. Kosma, D. LambropoulouSeasonal occurrence, removal, mass loading and environmental risk assessment of 55 pharmaceuticals and personal care products in a municipal wastewater treatment plant in Central Greece

Sci. Total Environ., 543 (2016), pp. 547-569, 10.1016/j.scitotenv.2015.11.047

Pereira et al., 2003

M.F.R. Pereira, S.F. Soares, J.J.M. Órfão, J.L. FigueiredoAdsorption of dyes on activated carbons: influence of surface chemical groups

Carbon N. Y., 41 (2003), pp. 811-821, 10.1016/S0008-6223(02)00406-2

Qiang and Adams, 2004

Z. Qiang, C. AdamsPotentiometric determination of acid dissociation constants (pKa) for human and veterinary antibiotics

Water Res., 38 (2004), pp. 2874-2890, 10.1016/j.watres.2004.03.017

$\underline{\text { Rediguieri et al., } 2011}$

C.F. Rediguieri, V. Porta, D.S.G. Nunes, T.M. Nunes, H.E. Junginger, S. Kopp, K.K. Midha, V.P. Shah, S. Stavchansky, J.B. DressmanBiowaiver monographs for immediate release solid oral dosage forms: metronidazole

J. Pharm. Sci., 100 (2011), pp. 1618-1627, 10.1002/jps

$\underline{\text { Reungoat et al., } 2012}$

J. Reungoat, B.I. Escher, M. Macova, F.X. Argaud, W. Gernjak, J. KellerOzonation and biological activated carbon filtration of wastewater treatment plant effluents

Water Res., 46 (2012), pp. 863-872, 10.1016/j.watres.2011.11.064

$\underline{\text { Article }}$

$\underline{\text { Rivera-Utrilla et al., } 2010}$

J. Rivera-Utrilla, M. Sánchez-Polo, G. Prados-Joya, M.A. Ferro-García, I. Bautista-ToledoRemoval of tinidazole from waters by using ozone and activated carbon in dynamic regime

J. Hazard. Mater., 174 (2010), pp. 880-886, 10.1016/j.jhazmat.2009.09.059 


\section{$\underline{\text { Rivera-Utrilla et al., } 2013}$}

J. Rivera-Utrilla, M. Sánchez-Polo, M.Á. Ferro-García, G. Prados-Joya, R. Ocampo-PérezPharmaceuticals as emerging contaminants and their removal from water. A review

Chemosphere, 93 (2013), pp. 1268-1287, 10.1016/j.chemosphere.2013.07.059

Rodríguez-Reinoso, 2001

F. Rodríguez-ReinosoActivated carbon and adsorption

Encyclopedia of Materials: Science and Technology, Elsevier Science Ltd, Oxford (2001), pp. 22-35

https://doi.org/10.1016/B0-08-043152-6/00005-X

$\underline{\text { Roskill, } 2016}$

RoskillCarbon \& Chemicals: 2016, the Year in Review for Activated Carbon [WWW Document]

(URL)

https://roskill.com/news/carbon-chemicals-2016-year-review-activated-carbon/ (2016), Accessed 5th Jul 2018

$\underline{\text { Royer et al., } 2009}$

B. Royer, N.F. Cardoso, E.C. Lima, V.S.O. Ruiz, T.R. Macedo, C. AiroldiOrganofunctionalized kenyaite for dye removal from aqueous solution J. Colloid Interface Sci., 336 (2009), pp. 398-405, 10.1016/j.jcis.2009.04.025

$\underline{\text { Sande-Bruinsma et al., } 2008}$

N. Sande-Bruinsma, H. Grundmann, D. Verloo, E. Tiemersma, J. Monen, H. Goossens, M. FerechAntimicrobial drug use and resistance in Europe Emerg. Infect. Dis., 14 (2008), pp. 1722-1730

$\underline{\text { Santos et al., } 2013}$

L.H.M.L.M. Santos, M. Gros, S. Rodriguez-Mozaz, C. Delerue-Matos, A. Pena, D. Barceló, M.C.B.S.M. MontenegroContribution of hospital effluents to the 
load of pharmaceuticals in urban wastewaters: identification of ecologically relevant pharmaceuticals

Sci. Total Environ., 461-462 (2013), pp. 302-316, 10.1016/j.scitotenv.2013.04.077

Snyder et al., 2007

S.A. Snyder, S. Adham, A.M. Redding, F.S. Cannon, J. DeCarolis, J. Oppenheimer, E.C. Wert, Y. YoonRole of membranes and activated carbon in the removal of endocrine disruptors and pharmaceuticals

Desalination, 202 (2007), pp. 156-181, 10.1016/j.desal.2005.12.052

$\underline{\text { Article }}$

Srinivasan and Viraraghavan, 2008

A. Srinivasan, T. ViraraghavanRemoval of oil by walnut shell media

Bioresour. Technol., 99 (2008), pp. 8217-8220, 10.1016/j.biortech.2008.03.072

Teijon et al., 2010

G. Teijon, L. Candela, K. Tamoh, A. Molina-Díaz, A.R. FernándezAlbaOccurrence of emerging contaminants, priority substances $(2008 / 105 / C E)$ and heavy metals in treated wastewater and groundwater at Depurbaix facility (Barcelona, Spain)

Sci. Total Environ., 408 (2010), pp. 3584-3595, 10.1016/j.scitotenv.2010.04.041

Teixeira et al., 2008

S. Teixeira, C. Delerue-Matos, A. Alves, L. SantosFast screening procedure for antibiotics in wastewaters by direct HPLC-DAD analysis

J. Sep. Sci., 31 (2008), 10.1002/jssc. 200800229

Teixeira et al., 2012

S. Teixeira, C. Delerue-Matos, L. SantosRemoval of sulfamethoxazole from solution by raw and chemically treated walnut shells

Environ. Sci. Pollut. Res., 19 (2012), 10.1007/s11356-012-0853-9 
A. Tello, B. Austin, T.C. TelferSelective pressure of antibiotic pollution on bacteria of importance to public health

Environ. Health Perspect., 120 (2012), pp. 1100-1106, 10.1289/ehp.1104650

Thiele-Bruhn, 2003

$\mathrm{S}$. Thiele-BruhnPharmaceutical antibiotic compounds in soils - a review

J. Plant Nutr. Soil Sci., 166 (2003), pp. 145-167, 10.1002/jpln.200390023

Tolls, 2001

J. TollsCritical review sorption of veterinary pharmaceuticals in soils: a review

Environ. Sci. Technol., 35 (2001), pp. 3397-3406

$\underline{\text { Vieno et al., } 2007}$

N.M. Vieno, H. Härkki, T. Tuhkanen, L. KronbergOccurrence of pharmaceuticals in river water and their elimination in a pilot-scale drinking water treatment plant

Environ. Sci. Technol., 41 (2007), pp. 5077-5084, 10.1021/es062720x

$\underline{\mathrm{Wu} \text { and Fassihi, } 2005}$

Y. Wu, R. FassihiStability of metronidazole, tetracycline $\mathrm{HCl}$ and famotidine alone and in combination

Int. J. Pharm., 290 (2005), pp. 1-13, 10.1016/j.ijpharm.2004.10.015

Yang et al., 2011

W. Yang, F. Zheng, X. Xue, Y. LuInvestigation into adsorption mechanisms of sulfonamides onto porous adsorbents

J. Colloid Interface Sci., 362 (2011), pp. 503-509, 10.1016/j.jcis.2011.06.071

Zhang et al., 2010

D. Zhang, B. Pan, H. Zhang, P. Ning, B. XingContribution of different sulfamethoxazole species to their overall adsorption on functionalized carbon nanotubes

Environ. Sci. Technol., 44 (2010), pp. 3806-3811 